\title{
Comparative study for the production of the male Nile tilapia between inter- specific hybridization and hormonal sex reversal.
}

\section{Nabil F. Abd Al-Hakim ${ }^{1}$; Esam H. Rizkalla ${ }^{2}$; Mohsen S. Hessen ${ }^{1}$;} Ahmed Z. Hegazi ${ }^{3}$ Al-Azab M. Tahoun ${ }^{4}$ and Ayman I. Khalfalla ${ }^{1}$

1- Animal Production Dept., Faculty of Agriculture, Al-Azhar University, Cairo, Egypt.

2- Biochemistry Dept., Animal Health Res. Inst., Agric. Res. Cen., Dokki, Giza, Egypt. 3- Arab Company for Fisheries, Abbassa, Abu Hammad, Sharkia, Egypt.

4- Aquaculture Dept., Faculty of Fish Resources, Suez Canal University, Suez, Egypt.

\section{ABSRRACT}

Tilapia fry were produced by hybridization of males of blue tilapia (Oreochromis aureus) with females of Nile tilapia (O. niloticus) and by sex reversal using oral administration of 3 doses (60, 80 and $100 \mathrm{mg} / \mathrm{kg}$ diet) of the androgen $17 \alpha$ methyltestosterone (MT) for 28 days. Fry were fattening in earthen ponds for 210 days.

All treatment groups that received androgen $\mathrm{MT}\left(\mathrm{T}_{3}, \mathrm{~T}_{4}\right.$ and $\left.\mathrm{T}_{5}\right)$ showed sex reversal with a significantly higher males proportion than females as compared to the control $\left(T_{2}\right)$ and hybrid $\left(T_{1}\right)$ groups. The treatment group that received $60 \mathrm{mg}$ MT $\left(T_{3}\right)$ exhibited the best growth performance parameters (average weight gain, average daily gain and specific growth rate) and feed utilization parameters (feed conversion ratio, protein efficiency ratio, protein production value and energy utilization). The highest percentage of body crude protein; ether extract and ash were detected in $\mathrm{T}_{3}$ group. With regard to human food safety, tilapias that treated with MT ( $T_{3}, T_{4}$ and $T_{5}$ ) rapidly excrete ingested hormone and MT levels falling to lower concentrations than that in both hybrid $\left(\mathrm{T}_{1}\right)$ and control $\left(\mathrm{T}_{2}\right)$ groups.

Keywords: Tilapia, Hybridization, $17 \alpha$-methyltestosterone, Sex Reversal, Growth Performance, Feed Utilization, Body Composition and Human Food Safety.

\section{INTRODUCTION}

Tilapias are of high importance in world fisheries, and Nile tilapia, Oreochromis niloticus accounted for a harvest of nearly 2.54 million tones in 2009 (FAO, 2011), second only to carp as a warm water food fish. One of the basic factors in tilapia aquaculture is that male fish grows bigger and faster than the female. Also, in order to avoid unwanted spawning in a production unit, an all-male population is preferred (Dan and Little, 2000; Carandang, 2007 and Abdul Mateen, 2007). Several methods for controlling reproduction have been attempted such as inter-specific hybridization, combined stocking with previous fishes, irradiation, monosex culture, cage culture, gynogenesis and sex reversal. Of all methods applied, hormonal sex reversal seems to be the most promising and accepTable techniques. Tilapias are easy to culture and reproduce, with rapid sexual maturation and become markeTable at 6-7 months from hatching. Nile tilapia is also an excellent laboratory animal that deserves to be studied (Maclean et al., 2002).

Synthetic androgens are used in fish culture as sex controlling agents and as growth promotors if energy is shut away from developing ovaries towards growth of somatic tissues (Al-Asaly, 2004 and Rizkalla et al., 2004). The more common method of generating mostly male populations is through the use of steroids fed to sexually 
undifferentiated fry. Newly hatched tilapia still developing their gonads, even though they are determined genotypically, their phenotype or morphological characteristics can still be altered. By exposing the fish to forms of testosterone or estrogen, the gonad can switch. Typically the desire is to produce all males, so methyltestosterone (MT) is included in the diet for several weeks when the fish starts eating. Studies involving sex reversal of Nile tilapia species using $17 \alpha$-methyltestosterone is well documented. Numerous papers have reported that $60 \mathrm{mg} / \mathrm{kg}$ was found to induce mono-sex male populations (Macintosh et al., 1988; Killian and Kohler, 1991; Green and Teichert-Coddington, 1994; Nuanmanee et al., 2004 and Vorasayan and Petchrich, 2004).

Anabolic steroids are potentially useful compounds in aquaculture due to their ability to increase weight gains and muscle deposition of treated fish. In Egypt, there is a considerable interest in extending the culture of the Nile tilapia; O. niloticus, which gives a good quality fish with a high marketability and excellent growth rates (Kheir et al., 1998). Dan and Little (2000) and Khalil et al. (2011) compared the culture performance of $O$. niloticus and found that MT treatment resulted in a final size of fish larger than mixed sex fish.

The present study was conducted to evaluate the potential effect of the hybridization between males $O$. aureus with females $O$. niloticus in producing all male offspring compared to the treatment of fry produced by normal mating of males and females $O$. niloticus with different oral doses of $17 \alpha$-methyltestosterone to produce sex reversal monosex tilapia fry. Also the present study aimed to investigate the effects of the performed treatments on the growth performance, feed utilization efficiency, carcass composition and human food safety of the resulting tilapia fry.

\section{MATERIALS AND METHODS}

\section{Fry production}

Fry were produced in the fish hatchery of Arab Fisheries Co. from brood stocks (250 g average body weight) using 2 ways:

(1) Hybridization method: 48 males blue tilapia (O. aureus) and 48 females Nile tilapia (O. niloticus) were stocked in two concrete ponds ( $3 \times 8 \times 1 \mathrm{~m})$ at a ratio $1: 1$.

(2) Sex reversal: Healthy 48 males and 144 females Nile tilapia (O. niloticus) were stocked in two concrete ponds $\left(24 \mathrm{~m}^{3}\right)$. Fish were stocked at a sex ratio of one male: 3 females. Produced fry were sex reversed using oral administration of synthetic androgen $17 \alpha$-methyltesterone (MT).

Both trails of mating started at the first of February 2008 and the brood stock ponds were covered with plastic sheets and aerated using a blower. During the mating period, pond water temperature was kept at $26 \pm 1^{\circ} \mathrm{C}$, using a water boiler. The parents brood stocks were fed during the mating period on a floating pelleted $(3 \mathrm{~mm}$ diameter) diet purchased from Zoo Control Company. The diet contains $35 \%$ protein and fed at a rate of $3 \%$ of pond biomass daily. The calculated daily diet was divided into two equal portions and fed two times at 9 am and $2 \mathrm{pm}$. The newly hatched fry were collected from the mouth of females and transferred thereafter carefully to fiberglass tanks separately for each mating and kept in the tanks for 48 hours for complete absorption of yolk-sac. After that the fry were sieved to remove the extra large fry before performing the sex reversal hormonal treatments. The fry used for the hormonal treatments have a length range 9 - 11 mm (Popma and Green, 1990). 


\section{Fry stocking:}

The newly hatched fry produced from hybridization were stocked in two fiberglass tanks (group 1, $\mathrm{T}_{1}$ ). The newly hatched fry for hormonal sex reverse were stocked in 8 fiberglass tanks represent 4 treatments in duplicate/treatment. Treatment zero MT/kg diet was considered as a control group (group 2, $\mathrm{T}_{2}$ ). The other three treatments were fed diet containing 60, 80 and $100 \mathrm{mg} \mathrm{MT} / \mathrm{kg}$ diet to represent the groups $3\left(\mathrm{~T}_{3}\right) ; 4\left(\mathrm{~T}_{4}\right)$ and $5\left(\mathrm{~T}_{5}\right)$ respectively. The five groups were stocked at a rate of 2000 fry/tank $\left(1 \mathrm{~m}^{3}\right)$. All fiberglass tanks were supplied with continuous circulation of water from a boiler and the water temperature was maintained at $26 \pm 1^{\circ} \mathrm{C}$. Tanks were continuously aerated, and $20 \%$ of the water volume was exchanged daily. Water quality was monitored at a range of $\mathrm{pH}$ (7.6 - 8.0), using pen type HANNA pH-meter; ammonia nitrogen $\left(\mathrm{NH}_{3}-\mathrm{N}\right)$ at less than $0.2 \mathrm{mg} / \mathrm{l}$ respectively and dissolved oxygen at above $6 \mathrm{mg} / \mathrm{l}$, using waterproof DO-meter (HI 9146-04) produced by Hanna Instrument Co.

One gram of17 $\alpha$-methyltestesterone obtained from Argent Chemical, Philippine was dissolved in one liter of $95 \%$ ethanol to prepare the stock solution of the hormone. The experimental doses (60, 80 and $100 \mathrm{mg} \mathrm{MT/kg} \mathrm{diet)} \mathrm{were} \mathrm{prepared}$ from the stock solution, using $95 \%$ ethyl alcohol as described by Popma and Green (1990). The prepared doses were spread on one kg grained feed (40\% protein, Table 2), mixed carefully and allowed the alcohol to evaporate for $48 \mathrm{~h}$ away from sun light. For the hybridization $\left(T_{1}\right)$ and control $\left(T_{2}\right)$ treatments, fry were fed the same grained feed without hormone by the same regime and under the same condition. The treatments applied are summarized in Table (1).

Table 1: The feeding regime of fry during 28 days.

\begin{tabular}{|c|c|c|c|}
\hline Week & Feeding rate of biomass & Average fry wt. (g) & Amount of diet (g)/day/treatment \\
\hline $1^{\text {st }}$ & $30 \%$ & 0.01 & 6 \\
\hline $2^{\text {nd }}$ & $25 \%$ & 0.05 & 25 \\
\hline $3^{\text {rd }}$ & $20 \%$ & 0.1 & 40 \\
\hline $4^{\text {th }}$ & $15 \%$ & 0.15 & 45 \\
\hline
\end{tabular}

\section{Fry stocking for growing period:}

After 28 days of treatment, fry $(0.18-0.19 \mathrm{~g})$ were harvested from each tank and transferred to a private fish farm at Tolombat \# 7, Kafr Elsheikh, for fattening period. Fifteen grow-out earthen ponds $(25 \mathrm{X} 10 \mathrm{X} 1.5 \mathrm{~m})$ were used (triplicate ponds/group). Fish were stocked at a rate of $4 \mathrm{fish} / \mathrm{m}^{3}$ with a total density of 1000 fish/pond. The inlets of all ponds were properly screened with nylon wired gauze of fine mesh to avoid the entry of wild fish or exit of fish from the pond.

The grow-out time lasted for 210 days, started from April and ended on October 31, 2008. Fish were fed with formulated diet (25\% crude protein, Table 2) at a rate of $3 \%$ of the body weight for the first 90 days then reduced to $2 \%$ of the fish body weight to the end of the experiment. A random sample of fish was taken every fifteen days to monitor average body weight for adjustment of feed intake. 
Table 2 Proximate analysis of experimental diets.

\begin{tabular}{|c|c|c|}
\hline Proximate analysis (\%) & $40 \%$ crude protein (Fry diet) & $\begin{array}{c}\text { 25\% crude protein } \\
\text { (Fatting diet) }\end{array}$ \\
\hline Dry matter & 90.0 & 89.0 \\
\hline Crude protein & 40.25 & 25.300 \\
\hline Ether extract & 9.25 & 6.25 \\
\hline Crude fibre & 3.35 & 4.97 \\
\hline Ash & 8.95 & 10.1 \\
\hline Nitrogen free extract & 38.20 & 52.50 \\
\hline Metabolizable energy $^{*}$ Kcal/kg diet). & 3477 & 3893.68 \\
\hline Protein/Energy ratio (mg protein/Kcal ME) & 137.43 & 96.74 \\
\hline
\end{tabular}

*: Metabolizable energy (ME) calculated using values of 4.5, 8.1 and 3.49 Kcal for protein, fat and carbohydrate, respectively according to Pantha (1982).

The mean values of pond's water quality parameters measured throughout the whole experimental period (210 days) are tabulated in Table (3).

Table 3: Means \pm S.E. of water quality criteria during the experimental period.

\begin{tabular}{|c|c|c|c|c|c|c|c|}
\hline \multirow[t]{2}{*}{ Month } & \multicolumn{2}{|c|}{ Temperature $\left({ }^{\circ} \mathrm{C}\right)$} & \multirow[t]{2}{*}{$\mathrm{pH}$} & \multicolumn{2}{|c|}{$\begin{array}{l}\text { Dissolved oxygen } \\
\text { (mg/l) }\end{array}$} & \multirow{2}{*}{$\begin{array}{l}\text { TAN } \\
(\mathrm{mg} / \mathrm{l})\end{array}$} & \multirow{2}{*}{$\begin{array}{c}\text { Total } \\
\text { Alkalinity } \\
\text { (mg/l) }\end{array}$} \\
\hline & (am) & $(\mathrm{pm})$ & & $\mathrm{am}$ & $\mathrm{pm}$ & & \\
\hline April & $\begin{array}{c}20.72 \pm \\
0.008\end{array}$ & $\begin{array}{l}23.66 \pm \\
0.006\end{array}$ & $\begin{array}{c}8.42 \pm \\
0.008\end{array}$ & $\begin{array}{l}1.45 \pm \\
0.008\end{array}$ & $\begin{array}{l}7.86 \pm \\
0.023\end{array}$ & $\begin{array}{c}0.094 \pm \\
0.001\end{array}$ & $\begin{array}{c}172.4 \pm \\
1.038\end{array}$ \\
\hline May & $\begin{array}{c}22.62 \pm \\
0.013\end{array}$ & $\begin{array}{c}24.76 \pm \\
0.006\end{array}$ & $\begin{array}{c}8.86 \pm \\
0.004 \\
\end{array}$ & $\begin{array}{l}1.51 \pm \\
0.011 \\
\end{array}$ & $\begin{array}{l}.40 \pm \\
0.051 \\
\end{array}$ & $\begin{array}{c}0.098 \pm \\
0.001\end{array}$ & $\begin{array}{c}169.2 \pm \\
0.819\end{array}$ \\
\hline June & $\begin{array}{c}24.34 \pm \\
0.009\end{array}$ & $\begin{array}{l}25.14 \pm \\
0.006\end{array}$ & $\begin{array}{c}8.75 \pm \\
0.026\end{array}$ & $\begin{array}{l}1.51 \pm \\
0.007\end{array}$ & $\begin{array}{l}7.04 \pm \\
0.050\end{array}$ & $\begin{array}{c}0.096 \pm \\
0.001\end{array}$ & $\begin{array}{l}175.0 \pm \\
1.326\end{array}$ \\
\hline July & $\begin{array}{c}25.76 \pm \\
0.006\end{array}$ & $\begin{array}{c}26.58 \pm \\
0.008\end{array}$ & $\begin{array}{c}8.47 \pm \\
0.003 \\
\end{array}$ & $\begin{array}{l}1.52 \pm \\
0.006\end{array}$ & $\begin{array}{l}7.08 \pm \\
0.055\end{array}$ & $\begin{array}{c}0.106 \pm \\
0.001\end{array}$ & $\begin{array}{c}172.4 \pm \\
1.088\end{array}$ \\
\hline August & $\begin{array}{c}26.20 \pm \\
0.017\end{array}$ & $\begin{array}{c}29.62 \pm \\
0.008\end{array}$ & $\begin{array}{l}8.43 \pm \\
0.008\end{array}$ & $\begin{array}{l}1.53 \pm \\
0.007\end{array}$ & $\begin{array}{l}7.30 \pm \\
0.062\end{array}$ & $\begin{array}{c}0.110 \pm \\
0.002\end{array}$ & $\begin{array}{c}183.0 \pm \\
1.141\end{array}$ \\
\hline September & $\begin{array}{c}25.34 \pm \\
0.006\end{array}$ & $\begin{array}{l}28.16 \pm \\
0.006\end{array}$ & $\begin{array}{l}8.85 \pm \\
0.005\end{array}$ & $\begin{array}{l}1.49 \pm \\
0.014\end{array}$ & $\begin{array}{l}7.42 \pm \\
0.54\end{array}$ & $\begin{array}{c}0.094 \pm \\
0.002\end{array}$ & $\begin{array}{l}172.6 \pm \\
1.616\end{array}$ \\
\hline October & $\begin{array}{c}23.76 \pm \\
0.006\end{array}$ & $\begin{array}{c}25.88 \pm \\
0.017\end{array}$ & $\begin{array}{l}8.32 \pm \\
0.006 \\
\end{array}$ & $\begin{array}{l}1.54 \pm \\
0.004 \\
\end{array}$ & $\begin{array}{l}7.36 \pm \\
0.049 \\
\end{array}$ & $\begin{array}{c}0.098 \pm \\
0.002\end{array}$ & $\begin{array}{c}179.2 \pm \\
0.638\end{array}$ \\
\hline
\end{tabular}

\section{Harvesting:}

At the end of experiment, sex differentiation was carried out manually by the visual method at harvesting in samples of $100 \mathrm{fish} /$ pond. Fish of each pond were counted and weighed. Survival rate was recorded. The growth performance parameters were calculated according to the following equations:

Average Weight Gain (AWG) = Average final weight (g) - Average initial weight (g) Average Daily Gain (ADG) = Average Weight Gain (g) / time (days)

Specific Growth Rate (SGR \%/day) = 100 [Ln Wt1 - Ln Wt $0 / \mathrm{t}$ ]

Where: Ln: normal log Wt 0: initial weight (g) Wt 1: final weight (g) t: time (days)

\section{Feed and protein utilization parameters:}

Feed and protein utilization parameters were calculated according to the following equations:

Feed Conversion Ratio (FCR) = Total feed consumption (g)/Weight gain (g)

Protein Efficiency Ratio (PER) = Body weight gain (g)/Protein intake (g)

Protein Production Value (PPV, \%) $=100$ [Retained protein (g)/Protein intake (g)] Energy Utilization $(\mathrm{EU}, \%)=100$ [Retained energy $(\mathrm{Kcal})] /$ energy intake $(\mathrm{Kcal})$ 


\section{Chemical analyses of ratios and fish carcass:}

Representative samples of the experimental fish from each pond were taken at the end of the experiment for carcass chemical analyses. Fish samples and samples of the experimental fish diets (fry and on-growing) were kept frozen $\left(-18^{\circ} \mathrm{C}\right)$ until performing the chemical analysis. All of the analyses were determined according to A.O.A.C. (1990).

\section{Hormonal analysis:}

Whole body samplings of the five fry groups (20 fry/tank) were taken immediately after the end of hormonal treatment (end of March, 2008) and for the next two months after grow-out period (i.e. April and May). From June 2008, carcass samplings of the five fish groups (10 fish/pond) were taken monthly till October 2008 (harvesting time). The method applied for testosterone extraction was recommended by Umberger et al. (1963). Testosterone hormone in the extract was estimated by enzyme linked immunosorbant assay (ELIZA) kit (DSL 10-4000) produced by the Diagnostic System Laboratories Incorporation (DSL), Texas, USA.

\section{Statistical analysis:}

Statistical analysis was done using SAS Version 9 (SAS Institute, 2002) statistical package. Data were statistically analysed using one way analysis of variance procedure. Mean of treatments were compared by Duncan multiple range test. Duncan test $(\mathrm{P}<0.05)$ was used to compare means and $(\mathrm{F}<0.05)$ was considered for the variance analyses.

\section{RESULTS AND DISCUSSION}

\section{1- Percentage of sex reversed fish:}

The percentages of sex reversed fish produced by hybridization method and MT treatments (0, 60, 80 and $100 \mathrm{mg} / \mathrm{kg}$ ) are presented in Figure (1). Highly significant $(\mathrm{P}<0.01)$ variations in the percentage of sex reversed fish among the five experimental groups were shown in this figure. These highly significant variations were obviously detected between $\mathrm{T}_{1}(76.1 \pm 0.006 \%)$ and $\mathrm{T}_{2}(53.4 \pm 0.006 \%)$ groups on one side and the hormonal reversed fish $\left(\mathrm{T}_{3}, \mathrm{~T}_{4}\right.$ and $\left.\mathrm{T}_{5}\right)$ on the other side. Insignificant differences were detected between the three groups treated with MT. The maximum male percentage (96.9 $\pm 0.260 \%$ ) was recorded in fish treated with $100 \mathrm{mg} \mathrm{MT} / \mathrm{kg}$ diet.

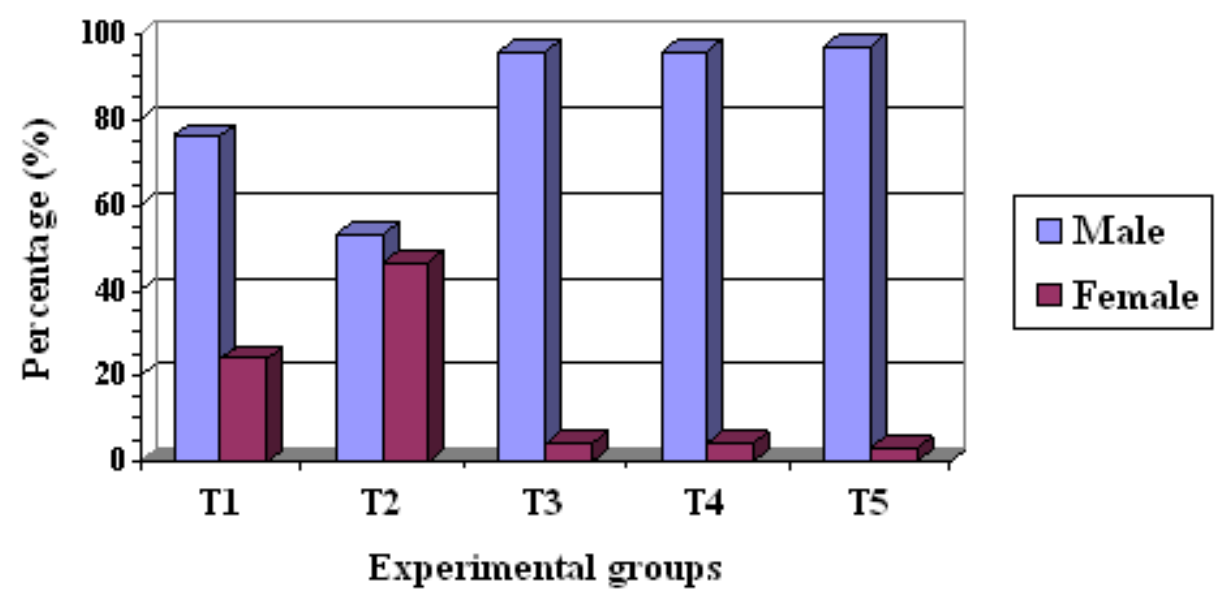

Fig. 1: Effect of hybridization and $17 \alpha$-methyltestosterone treatments for 28 days on sex ratio of hybrid and Nile tilapia fry on day 240 post hatching. 
Earlier crossing of male $O$. aureus with female $O$. niloticus conducted by Badawy and Rizkalla (1996) recorded $79.8-84.2 \%$ of male hybrids which is higher than that recorded in the present work (76.1\%).

Macintosh et al. (1988) and Abucay and Mair (1997) found that administration of $40 \mathrm{mg} \mathrm{MT} / \mathrm{kg}$ diet produced higher male sex reversal than $60 \mathrm{mg} \mathrm{MT} / \mathrm{kg}$, when they conducted the experiment in closed water system. On the other hand, Pongtana et al. (2004) utilized $60 \mathrm{mg} \mathrm{MT} / \mathrm{kg}$ to achieve $97.9 \pm 1.5 \%$ male sex tilapia for a period of 21 days. They reported that the incidence of intersex was consistently observed and suggested that the presence of readily available food in an earthen pond affected the efficiency of sex reversal using MT. It is important to notice that MT is an aromatizable androgen which means that it can be converted into estrogen by an enzyme produced in the liver called aromatase (Alfonso and Leboute, 2003). Al-Asaly (2004) found inter-sex individuals among O. niloticus fry fed with the MT dose of 60 mg and kept at the same exposure period (28 days).

Guerrero (1975) treated tilapia fry for 28 days with a dietary level of $30 \mathrm{mg}$ $\mathrm{MT} / \mathrm{kg}$ feed and claimed, based on the evidence of external sexual characters, that 95 - $98 \%$ of fish produced were males. Guerrero and Guerrero (1988) proposed $30 \mathrm{mg}$ $\mathrm{MT} / \mathrm{kg}$ diet for 21 days as the most promising dose resulting in $99 \%$ male $O$. niloticus. Boeck et al. (1992) produced $98 \%$ male on feeding $60 \mathrm{mg} \mathrm{MT} / \mathrm{kg}$ for 30 days at $21-23^{\circ} \mathrm{C}$. Vera Cruz and Mair (1994) treated Nile tilapia fry at $30 \mathrm{mg}$ MT/kg diet fed at $20 \%$ body weight for 25 days and obtained $98.4 \%$ males in tank and $95.4 \%$ males in hapas, while with $60 \mathrm{mg}$ MT treatment they obtained $99 \%$ males under similar conditions. The results in this study are in agreement with the finding of Popma and Green (1990) who found that oral administration of the synthetic androgen $17 \alpha$-methyltestosterone at $60 \mathrm{mg} / \mathrm{kg}$ feed to newly hatched tilapia fry (9 $11 \mathrm{~mm}$ total length) in hapas for a period of 28 days resulted in populations comprising 97 to $100 \%$ phenotype males. Also, Romerio et al. (2000) obtained $98 \%$ male population in Oreochromis sp., at a dose rate of $60 \mathrm{mg} \mathrm{MT} / \mathrm{kg}$ feed.

The results of this study disagree with the findings of Okoko (1996) who obtained $99.3 \%$ males at much lower dose (i.e. $30 \mathrm{mg}$ MT), while 97 and $71.9 \%$ males at the dose rates of 60 and $120 \mathrm{mg} \mathrm{MT} / \mathrm{kg}$ feed, respectively. Further, Abdul Mateen (2007) reported that higher dose rates (i.e. 240, 480, 600 and $1200 \mathrm{mg} \mathrm{MT} / \mathrm{kg}$ feed) resulted in no increase of male percentage.

Carandang (2007) cited that the use of $40 \mathrm{mg} \mathrm{MT} / \mathrm{kg}$ yielded male sex percentage statistically comparable to that of $60 \mathrm{mg} / \mathrm{kg}$ dosage. Hence, using both dosages could yield comparable effects in the earthen pond environment. Cagauan et al. (2004) mentioned that male sex reversal using MT has less efficiency when done in the natural environment, where food is present. This result plus the low stocking density (Phelps et al., 1995) suggest that the earthen pond provides a source of food aside from the artificial feed being offered, thus less treated feed may be taken in. Abucay and Mair (1997) were consistently successful in sex reversal of tilapia species, using $40 \mathrm{mg} \mathrm{MT} / \mathrm{kg}$ under closed water system.

Celik et al. (2011) found a significant difference among the groups feeding with feeds containing different rates of steroid in terms of sex reversal rates. The highest sex reversal occurred at 50 and $60 \mathrm{mg} \mathrm{MT} / \mathrm{kg}$ feed. The masculinization success was found to be high in comparison to the control group at doses of $20-40 \mathrm{mg} \mathrm{MT} / \mathrm{kg}$ feed. When the results of different doses were compared with each other, it was found that the results of $50 \mathrm{mg} \mathrm{MT/kg}$ feed dose and $60 \mathrm{mg} \mathrm{MT} / \mathrm{kg}$ feed dose were not different from each other, but were significantly different from the others $(0,20,30$ and $40 \mathrm{mg} \mathrm{MT} / \mathrm{kg}$ feed). Moreover, the effect of androgen on sex reversal depends on 
the type of application such as the method used, dose, fish age and size (DemskaZakes and Zakes, 1995). Therefore, specifying the environmental conditions, hormone type and the method used in such applications is of great importance for performing conscious commercial applications, the results of which can be estimated. The most preferred application is the method of adding steroid to the feed (Celik et al., 2011).

\section{Growth performance and survival rates:}

The average growth performance parameters of fry produced either by the hybridization method or MT treatments are presented in Table (4). It is clear from this Table that fry treated by $60 \mathrm{mg} \mathrm{MT} / \mathrm{kg}$ diet recorded the significant highest values of weight gain (332.8 $\pm 6.112 \mathrm{~g})$, daily weight gain $(1.387 \pm 0.026 \mathrm{~g})$ and specific growth rate $(3.127 \pm 0.014 \%)$. Fry of group $2\left(\mathrm{~T}_{2}\right)$ recorded the lowest values of weight gain $(249.5 \pm 2.917 \mathrm{~g})$, daily weight gain $(1.040 \pm 0.012 \mathrm{~g})$ and specific growth rate $(3.016 \pm 0.032 \%)$. The analysis of variance for the three growth parameters indicated a significant $(\mathrm{P}<0.05)$ difference between the five groups. ANOVA test supported the highly significant $(\mathrm{P}<0.01)$ differences among the five groups for both weight gain and daily weight gain and not for specific growth rate. Both ANOVA test and analysis of variance for survival rate did not show any significant variations between the 5 experimental groups. The survival rate ranged between $86.9 \pm 0.300 \%\left(\mathrm{~T}_{2}\right)$ and $87.6 \pm 0.033 \%\left(\mathrm{~T}_{3}\right)$. In general, data of the growth performance parameters revealed that treating the Nile tilapia fry after hatch with 60 $\mathrm{mg} \mathrm{MT} / \mathrm{kg}$ diet for 28 days showed the best results. The final body weight and net $O$. niloticus production after 210 days showed a marked increase for all dose rates of 17 $\alpha$-methyltestosterone $\left(T_{3}, T_{4}\right.$ and $\left.T_{5}\right)$ than the $T_{1}$ (the hybridization) and $T_{2}$ (untreated) groups. These data clearly indicated that MT treatment enhances the growth rate and biomass production of Nile tilapia very efficiently.

Table 4: Mean \pm S.E. of growth performance parameters of tilapia as affected by experimental treatments.

\begin{tabular}{|c|c|c|c|c|c|c|}
\hline Groups & $\begin{array}{c}\text { Initial } \\
\text { weight (g) }\end{array}$ & $\begin{array}{c}\text { Final weigh } \\
\text { (g) }\end{array}$ & $\begin{array}{l}\text { Weight gain } \\
\text { (g) }\end{array}$ & $\begin{array}{c}\text { Daily } \\
\text { weight gain } \\
\text { (g) }\end{array}$ & $\begin{array}{c}\text { Specific } \\
\text { growth rate } \\
(\%)\end{array}$ & $\begin{array}{l}\text { Survival } \\
\text { rate (\%) }\end{array}$ \\
\hline $\mathrm{T}_{1}$ & $\begin{array}{c}0.177^{\mathrm{a}} \pm \\
0.003\end{array}$ & $\begin{array}{c}285.0^{\mathrm{C}} \pm \\
2.887\end{array}$ & $\begin{array}{c}284.8^{\mathrm{c}} \pm \\
2.887\end{array}$ & $\begin{array}{c}1.187^{\mathrm{C}} \pm \\
0.012\end{array}$ & $\begin{array}{c}3.078^{\mathbf{a b}} \pm \\
0.009\end{array}$ & $\begin{array}{c}87.2^{\mathrm{a}} \pm \\
0.300\end{array}$ \\
\hline $\mathrm{T}_{2}$ & $\begin{array}{c}0.180^{\mathrm{a}} \pm \\
0.012\end{array}$ & $\begin{array}{c}249.7^{d} \pm \\
2.906\end{array}$ & $\begin{array}{c}249.5^{\mathrm{d}} \pm \\
2.917\end{array}$ & $\begin{array}{c}1.040^{\mathrm{d}} \pm \\
0.012\end{array}$ & $\begin{array}{c}3.016^{\mathbf{b}} \pm \\
0.032\end{array}$ & $\begin{array}{c}86.9^{\mathrm{a}} \pm \\
0.300\end{array}$ \\
\hline $\mathrm{T}_{3}$ & $\begin{array}{c}0.183^{\mathrm{a}} \pm \\
0.003\end{array}$ & $\begin{array}{c}333.0^{\mathrm{a}} \pm \\
6.110\end{array}$ & $\begin{array}{c}332.8^{\mathrm{a}} \pm \\
6.112\end{array}$ & $\begin{array}{c}1.387^{\mathrm{a}} \pm \\
0.026\end{array}$ & $\begin{array}{c}3.127^{\mathrm{a}} \pm \\
0.014\end{array}$ & $\begin{array}{c}87.6^{\mathrm{a}} \pm \\
0.033\end{array}$ \\
\hline $\mathrm{T}_{4}$ & $\begin{array}{c}0.193^{\mathrm{a}} \pm \\
0.003\end{array}$ & $\begin{array}{c}308.3^{b} \pm \\
4.410\end{array}$ & $\begin{array}{c}308.1^{b} \pm \\
4.413\end{array}$ & $\begin{array}{c}1.284^{b} \pm \\
0.018\end{array}$ & $\begin{array}{c}3.073^{\mathrm{ab}} \pm \\
0.013\end{array}$ & $\begin{array}{c}87.2^{\mathrm{a}} \pm \\
0.367 \\
\end{array}$ \\
\hline $\mathrm{T}_{5}$ & $\begin{array}{c}0.190^{\mathrm{a}} \pm \\
0.006\end{array}$ & $\begin{array}{c}296.7^{b c} \pm \\
4.410\end{array}$ & $\begin{array}{c}296.5^{b c} \pm \\
4.415\end{array}$ & $\begin{array}{c}1.235^{b} \pm \\
0.018\end{array}$ & $\begin{array}{c}3.064^{\mathrm{ab}} \pm \\
0.019\end{array}$ & $\begin{array}{c}87.3^{a} \pm \\
0.167\end{array}$ \\
\hline ANOVA & $\mathrm{P}>0.05$ & $\mathrm{P}<0.01$ & $\mathrm{P}<0.01$ & $\mathrm{P}<0.01$ & $\mathrm{P}>0.05$ & $P>0.05$ \\
\hline
\end{tabular}

Means in the same column having different letters are significantly $(\mathrm{P}<0.05)$ different

The present results indicated that as tilapia male ratio increased (Fig. 2), the growth rates would be higher (Table 4) compared to female tilapia. In this connection, Beardmore et al. (2001) stated that the use of male tilapia fish is intrinsically desirable in a range of aquaculture production systems. Toguyeni et al. (2002) cited that males tilapia grow faster than females long before sexual maturity. This better growth in males could be attributed to higher allocation of metabolic energy into gametogenesis in females as compared to males. Some authors are of the view that any improved growth of androgen treated tilapia is more related to the superior growth of males than the more classical anabolic response related to enhanced protein synthesis and 
increase in muscle mass (Abdul Mateen, 2007). The higher growth rates of treated groups, in the present study, compared to untreated (i.e. more female ratios) might be due to increased energy being channeled towards metabolic maintenance and somatic growth in males while the females use considerable energy for spawning (Tran-Duy et al., 2008 and Chakraborty, 2010).

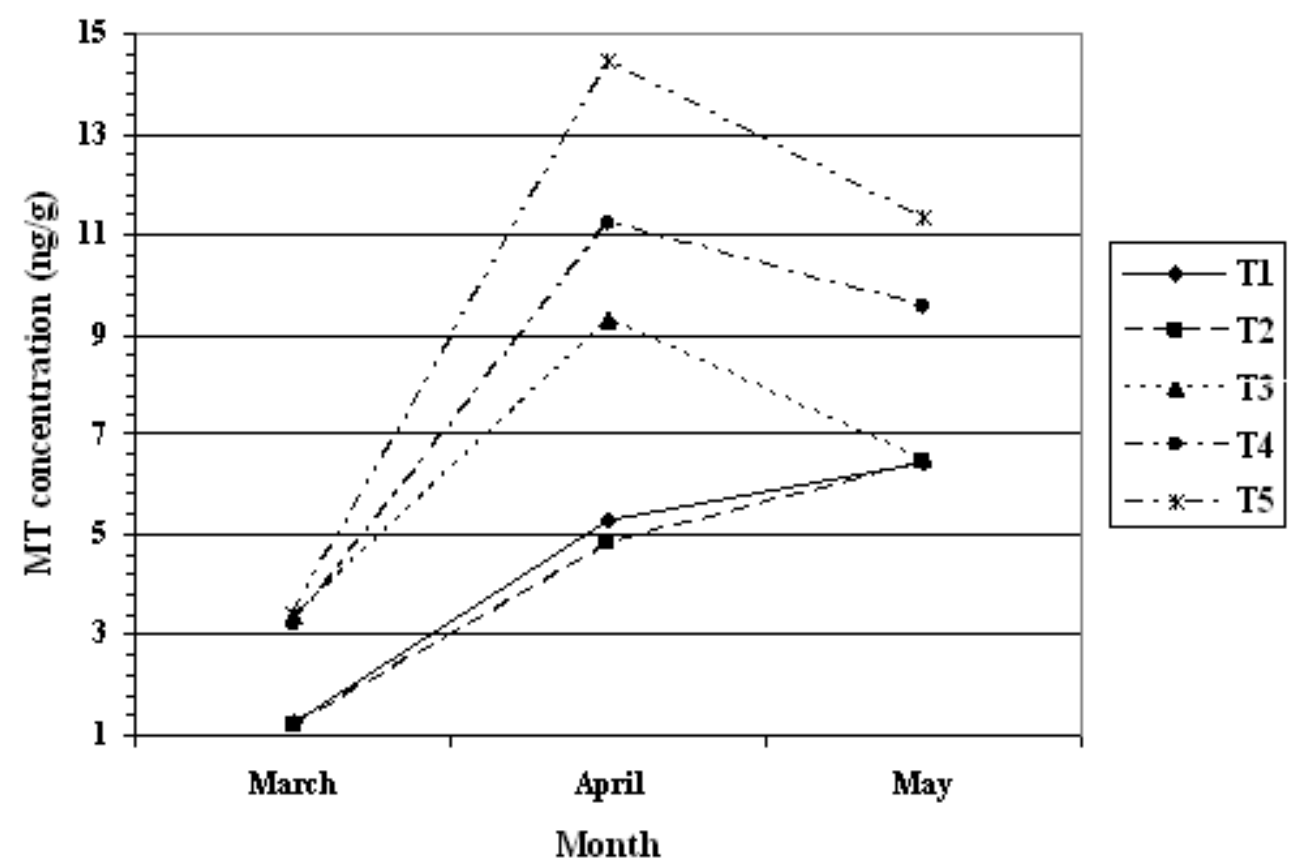

Fig. 2: Whole body MT concentrations in tilapia, as affected by experimental treatments.

The significant highest daily weight gain and specific growth rate recorded in $T_{3}$ group treated with the lowest dose of MT (Table 4) are in agreement with Chakraborty (2010). The primary indicator of growth performance in fish is fresh body weight. In this connection, some synthetic steroids are effective growthpromoting agents when administered at low doses. Pandian and Sheela (1995) reported that increasing mortality and decreasing growth are characteristic of treatment with increasing doses of estrogen and androgen, although growth promotion after such treatments has occasionally been reported. On the contrary, Turan and Akyurt (2005) concluded that the weight gain and specific growth rate of Claris gariepinus were significantly higher in fish fed the 50 and $75 \mathrm{mg} / \mathrm{kg}$ diets than in the control and $25 \mathrm{mg} / \mathrm{kg}$ groups. Androgens are effective growth promoters in channel catfish (Ictalurus punctatus; Gannam and Lovell, 1991); common carp (Cyprinus carpio; Pandian and Sheela, 1995) and bagrid catfish (Pseudobagrus fulvidraco; Park et al., 2003). These works examined a natural alternative to synthetic growth hormones in fish culture and revealed that androstenedione-based diets improved growth and increased the level of protein and fat in fish.

Some authors such as Woo et al. (1993) and Ahmad et al. (2002) supported the present results. The increase in body weight gain may be attributed to that androgen steroids enhance the release of growth hormone from the pituitary somatotrophs of fish and/or induce the feed digestion and absorption rate, causing increase in body weight (Khalil et al., 2011).

Similar to our results, Al-Asaly (2004) found no significant differences in survival rates among treated and un-treated fish groups. Also, Turan and Akyurt 
(2005) reported no significant differences in survival rate between androstenedione hormone-treated and untreated groups of catfish Claris gariepinus. Contrarily, Mair et al. (1987) showed that augmenting the dose and timing of $17 \alpha$-MT had lowered the survival rate of tilapia. Mangawaya (1986) found that the survival rates of tilapia were higher in the control than $30 \mathrm{mg}$ MT/kg diet treated group. Pandian and Sheela (1995) concluded that a treatment involving synthetic steroid resulted in higher mortality of most fish species, thus masculinization with the male heteroametic species may lead to lower survival rates.

A few studies have demonstrated the enhanced yield of monosex male Nile tilapia populations under experimental conditions (Mair et al., 1995). In other tilapias, O. mossambicus also, $17 \alpha$ - MT treated fish was reported to show higher growth compared to the untreated fish reared under similar conditions (Macintosh et al., 1985). Dan and Little (2000) observed that on average, monosex tilapia grew more than $10 \%$ faster than mixed-sex fish in cages. Several studies are in agreement that testosterone produces muscle hypertrophy by increasing muscle protein synthesis (Bhasin et al., 2001 and Chakraborty, 2010).

Moreover, Dan and Little (2000), while observing the culture performance of monosex and mixed sex culture of three strains of Nile tilapia, reported that monosex fish grew significantly faster than mixed-sex fish. On the contrary, Vera-Cruz and Mair (1994) reported no effect of hormone on growth in O. niloticus. Working on the comparative study of growth and feed utilization efficiencies of sex reversed diploid and triploid Nile tilapia, Pechsiri and Yakupitiyage (2005) reported no significant difference in final body weight of these sex reversed species.

\section{Feed and protein utilization:}

Extending to Table (4) that the highest significant $(\mathrm{P}<0.01)$ weight gain is for fish treated with $60 \mathrm{mg} \mathrm{MT} / \mathrm{kg}$ diet, Table (5) documented that the same group of fish $\left(T_{3}\right)$ represents the more efficient group that utilized feed and protein compared to the other fish groups. Both tests of ANOVA and analysis of variance declared the presence of highly significant $(\mathrm{P}<0.01)$ variations of feed and protein utilization parameters among and between the five tested groups. The highest values of protein efficiency ratio (PER) "2.506 \pm 0.064 "; protein productive value (PPV) "51.475 \pm $1.429 \%$ \%" and energy utilization (EU) "25.954 $\pm 0.727 \%$ " and the lowest value of feed conversion ratio (FCR) " $1.755 \pm 0.046$ " were recorded in fish treated with $60 \mathrm{mg}$ $\mathrm{MT} / \mathrm{kg}$ diet compared to the control group $\left(\mathrm{T}_{2}\right)$ " $1.760 \pm 0.053 ; 35.392 \pm 1.144 \%$; $17.639 \pm 0.589 \%$ and $2.500 \pm 0.073$ for PER; PPV; EU and FCR respectively”. So, MT treatment significantly improved FCR; PER; PPV and EU parameters which suggests anabolism as theorized with the use of MT.

The increased growth performance and the greater feed and protein utilization of the androgen treated fish can surely be analyzed considering this knowledge. Abdelghany (1996) fed fingerlings of Nile tilapia (O. niloticus) diets containing $17 \alpha$ methyltestosterone at doses of $0,2,5$, or $8 \mathrm{mg} / \mathrm{kg}$ diet for 20 weeks. He found that fish receiving $2 \mathrm{mg} \mathrm{MT} / \mathrm{kg}$ diet exhibited significant higher weight gain and better FCR, PER and PPV than fish fed the control diet. Also, he reported that increasing the dietary concentration of MT above $2 \mathrm{mg} / \mathrm{kg}$ diet reduced fish growth and feed utilization efficiency, but not below that of control fed fish. The author added that the anabolic property of the dietary steroids became more visible after 10 weeks. Turan and Akyurt (2005) found that Clarias gariepinus fed hormone treated diets had significantly better FCR and PER and the apparent net protein utilization was significantly better in the 50 and $75 \mathrm{mg} / \mathrm{kg}$ groups than in the control. Chakraborty 
(2010) observed a general decrease in FCR and increase in PER for monosex fish than the mixed-sex ones. Such observation may be related to the fact that FCR decreases while PER increases with increased feeding rate. On the other hand, there were also varying results as to the MT treatments on FCR and weight gain. MT treatment was not a significant factor in terms of FCR and weight gain when treatment was done in natural environment unlike when it was done in closed or re-circulating water systems (Jo et al., 1988 and Carandang, 2007).

Table 5: Mean \pm S.E. of feed and protein utilization parameters as affected by experimental treatments.

\begin{tabular}{|c|c|c|c|c|c|}
\hline Groups & $\begin{array}{c}\text { Feed } \\
\text { Intake (g) }\end{array}$ & $\begin{array}{c}\text { Feed conversion } \\
\text { ratio }\end{array}$ & $\begin{array}{c}\text { Protein } \\
\text { efficiency ratio }\end{array}$ & $\begin{array}{c}\text { Protein } \\
\text { productive } \\
\text { value (\%) }\end{array}$ & $\begin{array}{c}\text { Energy } \\
\text { utilization } \\
(\%)\end{array}$ \\
\hline $\mathrm{T}_{1}$ & $\begin{array}{c}571.7^{\mathrm{c}} \pm \\
7.265\end{array}$ & $\begin{array}{c}2.008^{\mathbf{b}} \pm \\
0.046\end{array}$ & $\begin{array}{c}2.189^{b} \pm \\
0.050\end{array}$ & $\begin{array}{c}43.86^{\mathbf{b}} \pm \\
0.748\end{array}$ & $\begin{array}{c}21.73^{b} \pm \\
0.358\end{array}$ \\
\hline $\mathrm{T}_{2}$ & $\begin{array}{c}623.3^{\mathrm{a}} \pm \\
12.019\end{array}$ & $\begin{array}{c}2.500^{\mathrm{a}} \pm \\
0.073\end{array}$ & $\begin{array}{c}1.760^{\mathrm{c}} \pm \\
0.053\end{array}$ & $\begin{array}{c}35.39^{\mathrm{c}} \pm \\
1.144\end{array}$ & $\begin{array}{c}17.64^{\mathrm{c}} \pm \\
0.589\end{array}$ \\
\hline $\mathrm{T}_{3}$ & $\begin{array}{c}583.7^{\mathbf{b c}} \pm \\
13.383\end{array}$ & $\begin{array}{c}1.755^{\mathrm{c}} \pm \\
0.046\end{array}$ & $\begin{array}{c}2.506^{\mathrm{a}} \pm \\
0.064\end{array}$ & $\begin{array}{c}51.48^{\mathrm{a}} \pm \\
1.429\end{array}$ & $\begin{array}{c}25.95^{\mathrm{a}} \pm \\
0.727\end{array}$ \\
\hline $\mathrm{T}_{4}$ & $\begin{array}{c}606.7^{\mathbf{a b}} \pm \\
6.009\end{array}$ & $\begin{array}{c}1.970^{\mathbf{b}} \pm \\
0.042\end{array}$ & $\begin{array}{c}2.231^{b} \pm \\
0.049\end{array}$ & $\begin{array}{c}45.41^{b} \pm \\
1.263\end{array}$ & $\begin{array}{c}22.88^{\mathbf{b}} \pm \\
0.676\end{array}$ \\
\hline $\mathrm{T}_{5}$ & $\begin{array}{c}575.7^{\mathrm{c}} \pm \\
2.963\end{array}$ & $\begin{array}{c}1.942^{\mathbf{b}} \pm \\
0.020\end{array}$ & $\begin{array}{c}2.262^{\mathbf{b}} \pm \\
0.024\end{array}$ & $\begin{array}{c}45.49^{\mathbf{b}} \pm \\
0.459\end{array}$ & $\begin{array}{c}22.93^{b} \pm \\
0.235\end{array}$ \\
\hline ANOVA & $\mathrm{P}<0.05$ & $\mathrm{P}<0.01$ & $\mathrm{P}<0.01$ & $\mathrm{P}<0.01$ & $\mathrm{P}<0.01$ \\
\hline
\end{tabular}

Means in the same column having different letters are significantly $(\mathrm{P}<0.05)$ different

\section{Body proximate composition:}

The collective data of the chemical body composition of the five groups of tilapia studied are summarized in Table (6). The differences of the five parameters among the different treatments were highly significant $(\mathrm{P}<0.01)$ as statistically analyzed by ANOVA test. The highest percentage of body moisture (68.87 $\pm 0.018 \%)$ was observed in $\mathrm{T}_{5}$ fish group, whereas crude protein (CP); ether extract (EE) and ash were detected in fish treated with $60 \mathrm{mg} \mathrm{MT} / \mathrm{kg}$ diet $(60.10 \pm 0.245 ; 18.28 \pm 0.071$ and $16.76 \pm 0.016 \%$ respectively).

Table 6: Mean \pm S.E. of body chemical composition of tilapia, as affected by experimental treatments.

\begin{tabular}{|c|c|c|c|c|c|}
\hline \multirow{2}{*}{ Groups } & Dry matter & Moisture & \multicolumn{3}{|c|}{ On dry matter (\%) } \\
\cline { 4 - 6 } & $(\%)$ & $(\%)$ & $C P$ & EE & Ash \\
\hline \multirow{2}{*}{$\mathrm{T}_{1}$} & $31.43^{\mathbf{b}} \pm$ & $68.57^{\mathbf{a}} \pm$ & $57.08^{\mathbf{a}} \pm$ & $16.53^{\mathbf{a}} \pm$ & $15.10^{\mathbf{a}} \pm$ \\
& 0.068 & 0.068 & 0.104 & 0.027 & 0.035 \\
\hline \multirow{2}{*}{$\mathrm{T}_{2}$} & $31.70 \mathrm{a}^{\mathbf{b}} \pm$ & $68.30^{\mathbf{a b}} \pm$ & $50.19^{\mathbf{b}} \pm$ & $14.77^{\mathbf{b}} \pm$ & $13.40^{\mathbf{b}} \pm$ \\
& 0.026 & 0.026 & 0.176 & 0.069 & 0.041 \\
\hline \multirow{2}{*}{$\mathrm{T}_{3}$} & $32.43^{\mathbf{a}} \pm$ & $67.57^{\mathbf{b}} \pm$ & $60.10^{\mathbf{c}} \pm$ & $18.28^{\mathbf{c}} \pm$ & $16.76^{\mathbf{c}} \pm$ \\
& 0.053 & 0.053 & 0.245 & 0.071 & 0.016 \\
\hline \multirow{2}{*}{$\mathrm{T}_{4}$} & $31.73^{\mathbf{a b}} \pm$ & $68.27^{\mathbf{a b}} \pm$ & $59.96^{\mathbf{c}} \pm$ & $18.20^{\mathbf{c}} \pm$ & $16.55^{\mathbf{d}} \pm$ \\
& 0.089 & 0.089 & 0.169 & 0.077 & 0.068 \\
\hline \multirow{2}{*}{$\mathrm{T}_{5}$} & $31.13^{\mathbf{b}} \pm$ & $68.87^{\mathbf{a}} \pm$ & $59.65^{\mathbf{c}} \pm$ & $18.12^{\mathbf{c}} \pm$ & $16.49^{\mathbf{d}} \pm$ \\
& 0.018 & 0.018 & 0.166 & 0.068 & 0.059 \\
\hline ANOVA & $\mathrm{P}<0.01$ & $\mathrm{P}<0.01$ & $\mathrm{P}<0.01$ & $\mathrm{P}<0.01$ & $\mathrm{P}<0.01$ \\
\hline
\end{tabular}

Means in the same column having different letters are significantly $(\mathrm{P}<0.05)$ different

The lowest value of body moisure (67.57 $\pm 0.053 \%)$ was shown in fish treated with $60 \mathrm{mg} \mathrm{MT} / \mathrm{kg}$, while values of CP (50.19 $\pm 0.176 \%)$; EE $(14.77 \pm 0.069 \%)$ and ash $(113.40 \pm 0.041 \%)$ were presented in control tilapia $\left(\mathrm{T}_{2}\right)$. Significant $(\mathrm{P}<0.05)$ differences in the percentages of $\mathrm{CP}$ and $\mathrm{EE}$ were detected by analysis of variance 
between both hybrid and control groups and the three groups treated with MT. No significant differences were observed between $T_{3}, T_{4}$ and $T_{5}$ fish groups. In case of ach percentages, significant $(\mathrm{P}<0.05)$ differences were calculated between the five fish groups but not between $\mathrm{T}_{4}$ and $\mathrm{T}_{5}$ groups.

These results showed that the body composition of tilapia was affected by hybridization and different MT treatments for sex reversal. Abdelghany (1996) fed fingerlings of Nile tilapia, $O$. niloticus, diets containing $17 \alpha$-methyltestosterone at doses of $0,2,5$, or $8 \mathrm{mg} \mathrm{MT} / \mathrm{kg}$ diet for 20 weeks. The results indicated an increase in moisture, protein, fat, and ash deposition in fish body, with the decrease of MT levels in the diet. Fish receiving $2 \mathrm{mg} \mathrm{MT} / \mathrm{kg}$ diet had greater retention values (by 47.7, 44.9, 20.8 and 35.1\% respectively) than did the control group. Turan and Akyurt (2005) experimented on carcass of channel catfish and found that moisture content was the same in all MT treated and untreated groups. The protein, lipid, and ash contents of the treated fish were significantly higher than in the control with the highest contents in the $50 \mathrm{mg} / \mathrm{kg}$ diet.

The present work demonstrated a trend towards accumulation of fat that was correlated with MT concentration. Contrary to that, Gannam and Lovell (1991) reported that androgens reduce fat deposition in channel catfish. Also working on sex reversed Nile tilapia, Mamun et al. (2004) and Pechsiri and Yakupitiyage (2005) found that the maximum moisture content (69.7 and $82.8 \%$ respectively) in meat had the lowest lipid content ( 7.15 and $2.4 \%$ respectively).

Pouomogne and Mbongblang (1993) and Abdelghany and Mohammed (2002) observed that the body protein content in Nile tilapia increases with wet weight. This explains the higher crude protein content of the treated fish than the corresponding control and hybrids in the present study. Changes in body composition, particularly in body fat content, might influence feed intake in fish (Tran-Duy et al., 2008).

\section{Human food safety:}

At the first three monthes of the experiment, $\boldsymbol{O}$. niloticus were very small and can not gain a representative muscle sample. So, concentrations of methyltestosterone were measured in the whole body as illustrated in Figure (2). ANOVA test showed highly significant $(\mathrm{P}<0.01)$ variations of MT concentrations among the five groups in these three monthes. Analysis of variance indicated significant $(\mathrm{P}<0.05)$ differences between the 5 experimental groups as follows: In March, between $T_{1}$ and $T_{2}$ on one side and the three groups of fish treated with MT on the other side, and no significant differences were detected between these three groups. In April, significant differences were recorded between the 5 groups. In May, $T_{4}$ and $T_{5}$ groups of fish illustrated significant differences between each other and between the other 3 groups $\left(T_{1}, T_{2}, T_{3}\right)$. Lowest concentrations of MT were recorded in hybrid and control fish, whereas the highest concentrations were detected in fish treated with $100 \mathrm{mg} \mathrm{MT} / \mathrm{kg}$ diet (3.453 \pm $0.015 ; 14.443 \pm 0.037$ and $11.327 \pm 0.026 \mathrm{ng} / \mathrm{g}$ in March, April and May respectively).

After the three monthes, fish became bigger and muscles can be obtained easily from them. So, MT concentrations were measured during the rest of the experimental period (June-October) on the muscles of the five groups studied and presented in Figure (3). As in the first 3 monthes, ANOVA showed highly significant $(\mathrm{P}<0.01)$ differences in the MT concentrations among the 5 groups of fish during the 5 monthes and analysis of variance illustrated the significant $(\mathrm{P}<0.05)$ variations between the 5 experimental groups. At June, the highest value of MT concentration was recorded in both $\mathrm{T}_{1}(9.6 \pm 0.008 \mathrm{ng} / \mathrm{g})$ and $\mathrm{T}_{5}(9.95 \pm 0.005 \mathrm{ng} / \mathrm{g})$ groups and the lowest value was in the $\mathrm{T}_{3}$ group ( $5.34 \pm 0.003 \mathrm{ng} / \mathrm{g}$ ). After that the highest value was restricted in $\mathrm{T}_{1}$ group in addition to $\mathrm{T}_{2}$ (control) group at August (10.340 $\pm 0.018 ; 10.233 \pm 0.012$ 
ng/g respectively) and October (1.88 $\pm 0.003 ; 1.85 \pm 0.008 \mathrm{ng} / \mathrm{g}$ respectively). The lowest value was recorded in $\mathrm{T}_{3}$ group to the end of the experiment $(4.49 \pm 0.022$; $3.41 \pm 0.065 ; 2.507 \pm 0.043$ and $1.73 \pm 0.005 \mathrm{ng} / \mathrm{g}$ from July to October respectively).

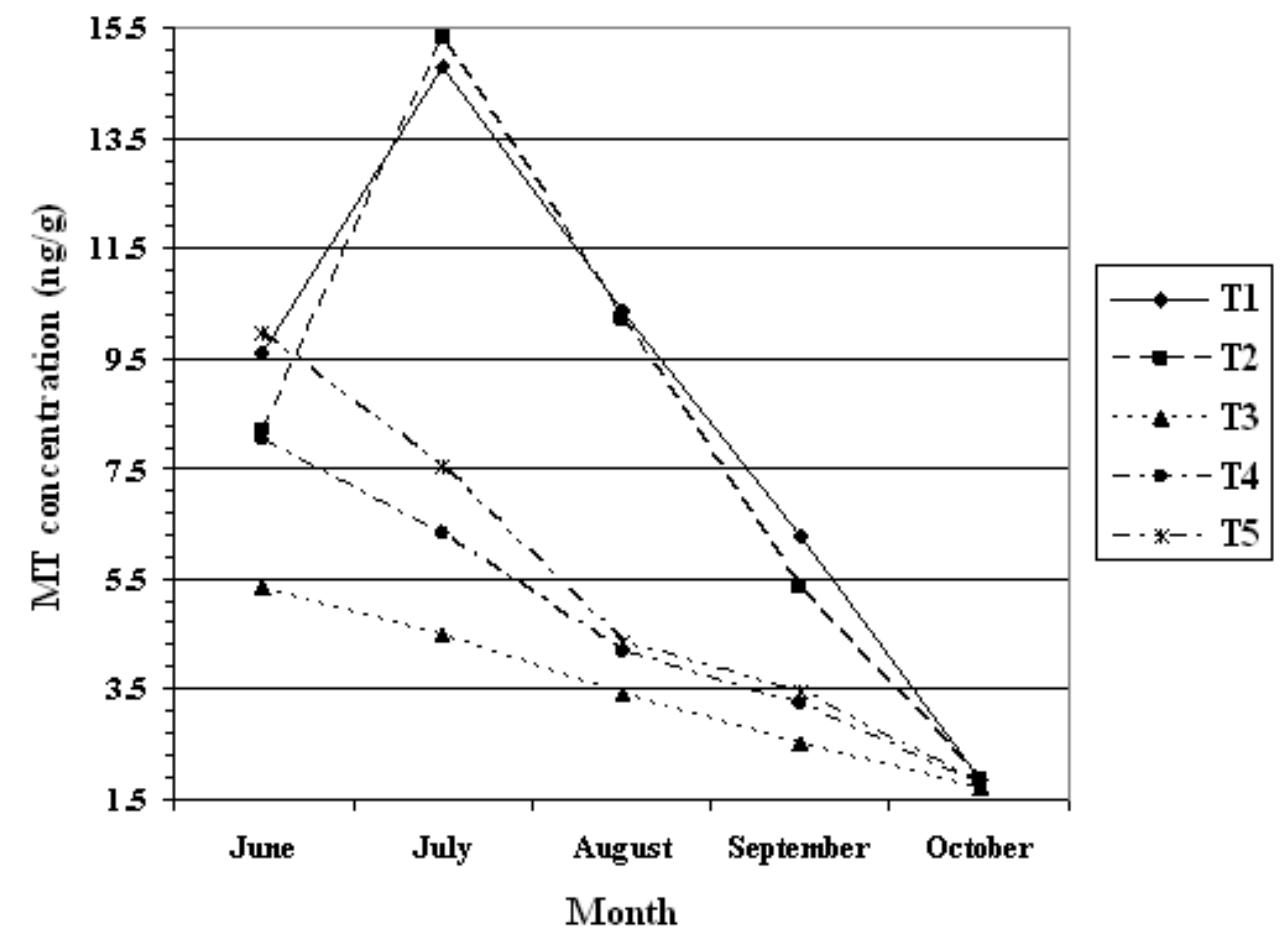

Fig. 3: Muscle MT concentrations in tilapia, as affected by experimental treatments.

The first published evaluation of the elimination patterns of high levels of 17MT (40 - $60 \mathrm{mg} / \mathrm{kg}$ feed) fed to sexually undifferentiated tilapia (O. mossambicus) was carried out by Johnstone et al. (1983). They found $95 \%$ of $17 \mathrm{MT}$ in the viscera by $20 \mathrm{~h}$ after the last MT feeding. By $50 \mathrm{~h}$, visceral levels had declined to less than $3 \%$ of their original value. One hundred hours after the withdrawal of the MT-treated diet, the whole fish body levels of MT were not detecTable. Macintosh et al. (1995) confirmed this observation and stated that tilapia rapidly excrete ingested MT and falling to less than $1 \%$ within 100 hours of withdrawing MT. Ingested $17 \alpha-$ methyltestosterone is metabolized rapidly into active and inactive metabolites, and excreted rapidly from the fish. Curtis et al. (1991) found that on the $1^{\text {st }}$ day after dosing of sexually undifferentiated $O$. niloticus with $30 \mathrm{mg}$ radioactive $17 \mathrm{MT} / \mathrm{kg}$ ration for 30 days only 2.5 - $3 \%$ of the whole body $17 \mathrm{MT}$ residues were identified as parent compound and $97 \%$ were polar metabolites. On the $3^{\text {rd }}$ day after dosing, $95 \%$ of radiolabeled 17MT had been converted to polar metabolites, which decreased to $70 \%$ by 7 days, and to only trace concentrations by day 10 . The biological half-lives for polar and parent compounds 17MT were 1.1 and 2.2 day respectively.

Goudie et al. (1986) showed a rapid depletion of radioactive methyltestosterone from tilapia muscle. $90 \%$ of the radioactive label was eliminated within $24 \mathrm{~h}$ and less than $1 \%$ of the original radioactivity could be detected 21 days after steroid withdrawal. If the entire residue persisted until the fish reached markeTable size, tissue levels would be $20 \mathrm{pg} \mathrm{MT} / \mathrm{g}$. As a result of either rapid sequestration of absorbed steroid by the liver and removal by the bile, or because of relatively poor rate of intestinal assimilation, absolute levels of $17 \mathrm{MT}$ in the fish carcasses were in 
the low parts per billion range (ng/g) upon completion of the withdrawal period (Johnstone et al., 1983 and Goudie et al., 1986). El-Nemr et al. (1999) recorded that the residual value of $17 \mathrm{MT}$ in $O$. niloticus fry muscle was significantly dropped after 6 weeks withdrawal period $(2.30 \pm 0.52 \mathrm{ng} / \mathrm{g})$ and still higher than the control group (0.05 $\pm 0.004 \mathrm{ng} / \mathrm{g})$. Green and Teichert-Coddington (2000) estimated the concentration of MT in skinless fillet to be $1.2-3.4 \mathrm{ng} / \mathrm{g}$. This range was based on a 21 day withdrawal period and does not take into consideration the metabolism and excretion associated with a longer withdrawal period. Recently, Khalil et al. (2011) collected samples of untreated and treated Nile tilapia with MT at several time intervals and found that the residual concentrations of the testosterone hormone in muscles of the Nile tilapia from the different studied sites were significant. The presence of hormone residues is not high in muscle tissue of the untreated and treated fish and decreased when the fish reached to the markeTable size.

Our results are in agreement with those of Rizkalla et al. (2004) who mentioned that during nursing season, whole body testosterone concentration in O. niloticus treated with $60 \mathrm{mg} 17 \mathrm{MT} / \mathrm{kg}$ diet for 28 days showed significantly higher values during the $1^{\text {st }}$ withdrawal month than the normal fish. In the $3^{\text {rd }}$ and $4^{\text {th }}$ withdrawal months, normal fish showed significantly higher values than the monosex ones. During growing-out season, muscle testosterone concentration in monosex tilapia was sharply decreased to $2.625 \pm 0.303 \mathrm{ng} / \mathrm{g}$ at the harvesting date. Finally, based on the scientific evidence that methyltestosterone is rapidly eliminated from fish and adult tilapia requires a grow out period of at least five months to reach markeTable size, so no health hazard for human consumption of adult fish fed MT as juveniles was indicated.

\section{CONCLUSION}

The use of $60 \mathrm{mg} / \mathrm{kg}$ MT produced statistically higher male sex percentage when done for 28 days post hatch with efficient feed and protein utilization and in turn attaining higher growth performance and survival rates. Moreover, Tilapia rapidly excrete ingested hormone, with MT levels falling to less than 1\% within 100 hours of withdrawing MT. Thus MT is not detecTable in adult tilapia, which require a grow out period of at least five months to reach markeTable size.

\section{REFERENCES}

A.O.A.C. "Association of Official Agricultural Chemists” (1990): Official methods of analysis. $15^{\text {th }}$ Ed. Published by the A.O.A.C., Benjamin Francklin Station, Washington. D. C., USA.

Abdelghany, A.E. (1996): Effects of feeding $17 \alpha$-methyltestosterone and withdrawal on feed utilization and growth of Nile Tilapia, Oreochromis niloticus L., Fingerlings. J. Applied Aquac., 5 (3): 67-76.

Abdelghany, A.E. and Mohammed, H.A. (2002): Effects of feeding rates on growth and production of Nile tilapia, common carp and silver carp polycultured in fertilized ponds. Aquac. Res., 33: 415-423.

Abdul Mateen (2007): Effect of androgen on the sex reversal, growth and meat quality of tilapia, Oreochromis niloticus. Ph.D. Thesis. University of Agriculture, Faisalabad. 
Abucay, J.S. and Mair, G.C. (1997): Hormonal sex reversal of tilapias: implications of hormone treatment application in closed water Systems. Aquac. Res., 28: 841845.

Ahmad, M.H.; Shalaby, A.M.E.; Khattab, Y.A.E. and Abdel-Tawwab, M. (2002): Effects of $17 \alpha$-methyl-testosterone on growth performance and some physiological changes of Nile tilapia fingerlings (Oreochromis niloticus L.). Egypt. J. Aquat. Biol. Fish, 4 (4): 295-311.

Al-Asaly, A.M.A. (2004): Some studies on steroid induced mono-sex Nile tilapia. M.Sc. Tesis. Fac. Vet. Medicine, Zagazig University.

Alfonso, L.O.B. and Leboute, E.M. (2003): Sex reversal in Nile tilapia: Is it possible to produce all-male stocks through immersion in androgens? World Aquac., Sep 16-19.

Badawy, E.A. and Rizkalla, E.H. (1996). Effect of the genetic status of Oreochromis niloticus and $O$. aureus from three localities on the male ratio of their hybrids. Bull. Nat. Inst. Oceanogr. \& Fish., A.R.E., 22: 255-266.

Beardmore, J.A.; Mair, G.C. and Lewis, R.I. (2001): Monosex male population in finfish as exemplified by tilapia applications, problems, and prospects. Aquaculture, 197: 283-301.

Bhasin, S.; Woodhouse, L. and Storer, T.W. (2001): Proof of the effect of testosterone on skeletal muscle. J. Endocrin., 170: 27-38.

Bocek, A.J.; Phelps, R.P. and Pompa, T.J. (1992): Effect of feeding frequency on sex reversal and growth of Nile tilapia Oreochromis niloticus. J. Applied Aquac., 1: 97-103.

Cagauan, A.G.; Baleta, F.N. and Abucay, J.S. (2004): Sex reversal of Nile Tilapia Oreochromis niloticus L. by egg immersion technique: The effect of hormone concentration and immersion time. Proc. $6^{\text {th }}$ Int. Symp. on tilapia in aquaculture. 12-16 September 2004. pp. 127-136.

Carandang, R.P. (2007) : Effect of butea superba and $17 \alpha$-methyltestosterone (MT) on sex reversal and some growth parameters in three strains (red, ghana and chitralada) of Nile tilapia (Oreochromis niloticus, L. Ph.D Thesis, Maejo University.

Celik, I.; Guner, Y. and Celik, P. (2011): Effect of orally-administered $17 \alpha$ methyltestosterone at different doses on the sex reversal of the Nile tilapia (Oreochromis niloticus, Linneaus 1758). J. Animal \& Veterinary Advances, 10: 853-857.

Chakraborty, S.B. (2010): Comparative growth performance of mixed-sex and monosex Nile tilapia population in freshwater cage culture system under Indian perspective. Int. J. Biol., 2 (1): 44-50.

Curtis, L.R.; Diren, F.T.; Hurley, M.D.; Seim, W.K. and Tubb, R.A. (1991): Disposition and elimination of $17 \alpha$-methyltestosterone in Nile tilapia (Oreochromis niloticus). Aquac., 99: 193-201.

Dan, N.C. and Little, D.C. (2000): The culture performance of monosex and mixedsex new-season and overwintered fry in three strains of Nile tilapia (Oreochromis niloticus) in northern Vietnam. Aquac., 184: 221-231.

Demska-Zakes, K. and Zakes, Z. (1995): Sex differentiation in pike perch (Stizostedion lucioperca L.). Arch. Pol. Fish., 3: 51-57.

El-Nemr, I.Z.; Haleem, H.H. and Abdou, K.A.H. (1999): Evaluation of the effect of $17 \alpha$-methyltestosterone on monosex, mortality rate and residual values in tilapia (Oreochromis niloticus). Beni-Suef Vet. Med. J., 9 (2): 25-33. 
FAO "Food and Agriculture Organization" (2011): The State of World Fisheries and Aquaculture. Rome, Italy.

Gannam, A.L. and Lovell, R.T. (1991): Effect of feeding 17 alpha methyltestosterone, 11-ketotestosterone, 17 beta-estradiol and 3,5,3'-triiodothyronine to channel catfish, Ictalurus punctatus. Aquac., 92: 377-388.

Green, B.W. and Teichert-Coddington, D.R. (1994): Growth of control and androgentreated Nile Tilapia, Oreochromis niloticus (L.), during treatment, nursery and grow-out phases in tropical fishponds. Aquaculture and Fisheries Management, 25: 613-621.

Green, B.W. and Teichert-Coddington, D.R. (2000). Human food safety and environmental assessment of the use of $17 \alpha$-methyltestosterone to produce male tilapia in the United States. J. World Aquaculture Society, 31: 337- 357.

Goudie, C.A.; Shelton, W.L. and Parker, N.C. (1986): Tissue distribution and elimination of radiolabelled methyltestosterone fed to sexually undifferentiated blue tilapia. Aquac., 58: 215-226.

Guerrero, R.D. III. (1975): Use of androgens for production of all male Tilapia aurea (Steindachner). Trans. Am. Fish. Soci., 2: 342-347.

Guerrero, R.D. III. and Guerrero, L.A. (1988): Feasibility of commercial production of Nile tilapia fingerlings in Philippines. In: The $2^{\text {nd }}$ Symposium on Tilapia in Aquaculture. ICLARM Conf. Proc. (ed. by R.S.V., Pullin; T. Bhukaswan; K. Tonguthi and J.L. Macleen). Int. Cen. for Living Aquatic Resource Management, Manila, Philippines, 15: 183-186.

Jo, J.Y.; Smitherman, R.O. and Behrends, L.L. (1988): Effects of dietary $17 \alpha$-methyltestosterone on sex reversal and growth of Oreochromis aureus. Proc. of the $2^{\text {nd }}$ Int. Symp. on Tilapia in Aquac., 15: 203-207.

Johnstone, R.; Macintosh, D.J. and Wright, R.S. (1983): Elimination of orally administered $17 \alpha$-methyltestosterone by Oreochromis mossambicus (tilapia) and Salmo gairdneri (rainbow trout) juveniles. Aquac., 35: 249-257.

Khalil, W.K.B.; Hasheesh, W.S.; Marie, A.S.; Abbas, H.H. and E.A. Zahran (2011): Assessment the impact of $17 \alpha$-methyl testosterone hormone on growth, hormone concentration, molecular and histopathological changes in muscles and testis of Nile tilapia; Oreochromis niloticus. Life Sci. J., 8 (3): 329-343.

Kheir, M.T.; Mechail, M.M. and Abo-Hegab, S. (1998): Growth of adult and newly hatched fry of Oreochromis niloticus reared at different saline concentrations. Egypt. J. Zool., 30: 107-115.

Killian, H.S. and Kohler, C.C. (1991): Influence of $17 \alpha$-methyltestosterone on red tilapia under two thermal regimes. J. World Aquaculture Soc., 22: 83-94.

Macintosh, D.J. and Little, D.C. (1995): Nile tilapia (Oreochromis niloticus). In: Bromage, N.R. and Roberts, R.J. (Editors). Broodstock management and egg and larval quality, Chapter 12. Blackwell Scientific Ltd., Cambridge, Massachusetts, USA, pp. 277-320.

Macintosh, D.J.; Varghese, T.J. and Satyanarayana, G.P. (1985): Hormonal sex reversal of wild-spawned tilapia in India. J. Fish Biol., 26: 87-94.

Macintosh, D.J., Singh, T.B.; Little, D.C. and Edwards, P. (1988): Growth and sexual development of $17 \alpha$-methyltestosterone-treated Nile Tilapia (Oreochromis niloticus) reared in earthen ponds. Proc. $2^{\text {nd }}$ Int. Symp. on Tilapia in Aquaculture, ICLARM Conference 15: 623 January 1990.

Maclean, N.; Rahman, M.A.; Sohm, F.; Hwang, G.; Iyengar, A.; Ayad, H.; Smith, A. and Farahmand, H. (2002): Transgenic tilapia and the tilapia genome. Gene, 295: 265-277. 
Mair, G.C.; Penman, D.J.; Scott, A.; Skibinski, D.O.F. and Beardmore, J.A. (1987): Hormonal sex-reversal and the mechanism of sex determination in Oreochromis. pp. 301-312. In: Proc. World Symp. on Selection, Hybridization and Genetic Engineering in Aquaculture, Vol. 2. Bordeaux, Berlin.

Mair, G.C.; Abucay, J.S.; Beardmore, J.A. and Skibinski, D.O.F. (1995): Growth performance trials of genetically male tilapia (GMT) derived from YY-males in Oreochromis niloticus L.: On station comparisons with mixed sex and sex reversed male populations. Aquac., 137: 313-322.

Mamun, S.M.; Focken, U.; Frances, G. and Becker, K. (2004): Growth performance and metabolic rates of genetically improved and conventional strains of Nile tilapia, Oreochromis niloticus L., reared individually and fed Ad libitum. In: Proc. Sixth Int. Symp. on Tilapia in Aquaculture. Hrsg: R.B. Bolivar, G.C. Mair and K. Fitzsimmons. Manila, Philippines. 379-399 pp.

Mangawaya, C.N. (1986): Influence of methyltestosterone on early growth and sex reversal of Oreochromis niloticus. Port hrcourt, Nigeria. African Regional Aquaculture Center. 62 pp.

Nuanmanee, P.; Siangwan, S. and Nitharn, J. (2004): Effects of androgens on sex reversal of Nile tilapia. Fisheries Magazine, 57: 251.

Okoko, M. (1996): Effect of $17 \alpha$-methyl testosterone concentration on the sex ratio and gonadal development of Nile tilapia Oreochromis niloticus. M.Sc. Thesis, Auburn University, Alabama, US.

Pandian, T.J. and Sheela, S.G. (1995): Hormonal induction of sex reversal in fish. Aquac., 138: 1-22.

Pantha, B. (1982): The use of soybean in practical feeds for Tilapia niloticus. M.Sc. Thesis. University of Stirling.

Park, I.S.; Oh, H.S. and Koo, J.G. (2003): Effect of oral tamoxifen on growth and survival in the bagrid catfish Pseudobagrus fulvidraco. Aquaculture Research, 34: 1471-1474.

Pechsiri, J. and Yakupitiyage, A. (2005): A comparative study of growth and feed utilization efficiency of sex reversed diploid and triploid Nile tilapia, Oreochromis niloticus. Aquac. Res., 36: 45-51.

Phelps, R.P.; Salazar, G.C.; Abe, V. and Argue, B.J. (1995): Sex reversal and nursery growth of Nile tilapia, Oreochromis niloticus (L.) free-swimming in earthen ponds. Aquaculture Research 26: 293-295.

Pongtana, N.; Siangwan, S. and Nitham, J. (2004): Effects of androgens on sex reversal of Nile tilapia. Fisheries Magazine, 57 (3): 111-120.

Popma, T.J. and, Green, B.W. (1990): Sex reversal of tilapia in earthen ponds. Int. Cen. for Aquaculture and Aquatic Environments Res. and Development. Series No. 35, Auburn University, Alabama, pp: 15.

Pouomogne, V. and Mbongblang, J. (1993): Effect of feeding rate on the growth of tilapia (Oreochromis niloticus) in earthen ponds. Israeli J. Aquaculture Bamideh, 45:147-153.

Rizkalla, E.H.; Haleem, H.H.; Abdel-Halim, A.M.M. and Youssef, R.H. (2004): Evaluation of using $17 \alpha$-methyl testosterone for monosex Oreochromis niloticus fry production. J. Egypt. Ger. Soc. Zool., 43A: 315-335.

Romerio, M-P C.S.; Fenerich-Verani, N.; Santo De-Campos, B.E. and Da-Silva, A.S. (2000): Masculinization of Nile tilapia, Oreochromis niloticus, using different diets and different doses of 17 alpha-methyl testosterone. Revista Brasileira de Zootecnia, 29 (3): 654-659. 
SAS Institute (2002). SAS. Software Version 8. SAS Institute Inc, Cary, North Carolina. United States of America.

Toguyeni, A.; Fauconneau, B.; Fostier, A.; Abucay, J., Mair, G. and Baroiller, J. (2002) : Influence of sexual phenotype and genotype, and sex ratio on growth performance in tilapia, Oreochromis niloticus. Aquaculture, 207: 249-261.

Tran-Duy, A.; Schrama, J.W.; van Dam, A.A. and Verreth, J.A.J. (2008): Effects of oxygen concentration and body weight on maximum feed intake, growth and haematological parameters of Nile tilapia, Oreochromis niloticus. Aquac., 275: 152-162.

Turan, F. and Akyurt, I. (2005): Effects of androstenedione, a phytoandrogen, on growth and body composition in the African catfish clarias gariepinus. Israeli J. Aquac. - Bamidgeh, 57 (1): 62-66.

Umberger, E.; Banes, D.; Kunze, F., Sylvia, H.A. and Colson, H. (1963): Chemical determination of diethyl stilboestrol residues in tissues of treated chicken. $\mathrm{J}$. A.O.A.C., 46: 441-479.

Vera Cruz, E.M. and Mair, G.C. (1994): Conditions for effective androgen sex reversal in Oreochromis niloticus (L.) Aquaculture, 122: 237-248.

Vorasayan, P. and Petchrich, N. (2004): Sex reverse tilapia seed production by using hormone mixed feed. Fisheries Magazine, 57: 251.

Woo, N.Y.S.; Chung, A.S.B. and Ng, T.B. (1993): Influence of oral administration of $17 \beta$-estradiol and testosterone on growth, digestion, food conversion and metabolism in the under yearling red sea bream, Chrysophrys major. Fish Physiol. Biochem., 10 (5): 377-387.

\section{ARABIC SUMMERY}

$$
\begin{aligned}
& \text { دراسة مقارنة لإنتاج زريعة بلطي وحيد الجنس بالتهجين بين الأنواع وباستخدام هرمون انعكاس الجنس }
\end{aligned}
$$

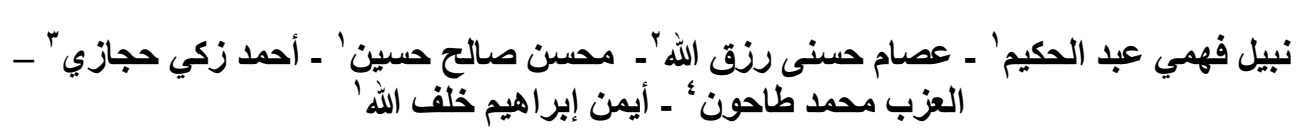

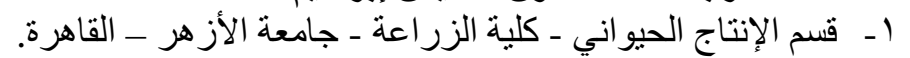

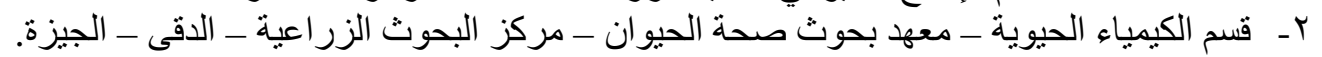

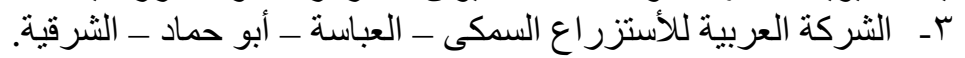

$$
\begin{aligned}
& \text { ع - فسم الاستزر اعة المائي - كلية الثروة السمكية - جامعة قناة السويس. } \\
& \text { فرخت يرقات البلطى بطريقتين: التهجين بتزاوج ذكور البلطي الازرق (اوريا) مع اناث البلطي النيلي وهرمونياً }
\end{aligned}
$$

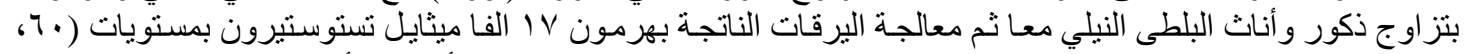

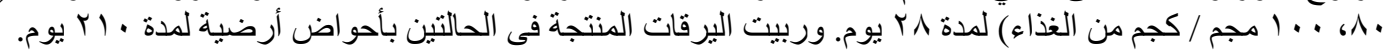

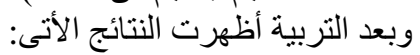

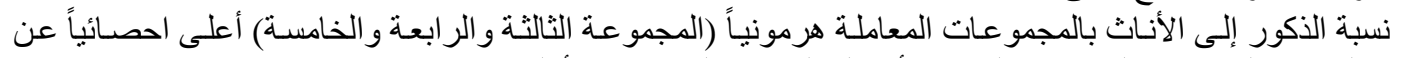

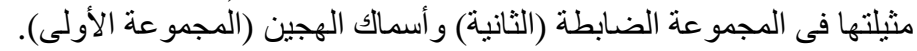

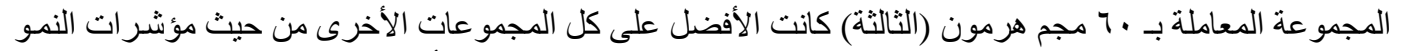

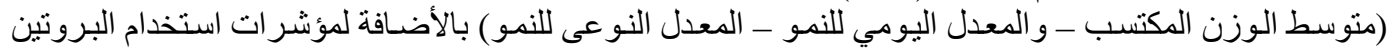

$$
\begin{aligned}
& \text { و الغذاء (معامل التحويل الغذائي ـ الكفاءة النسبية للبروتين - قيمة انتاجية للبروتين ـ كفاءة استخدام الطاقة). }
\end{aligned}
$$

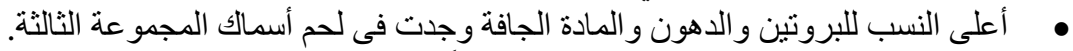

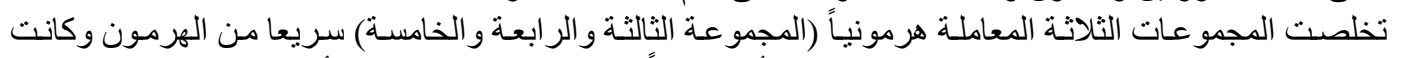

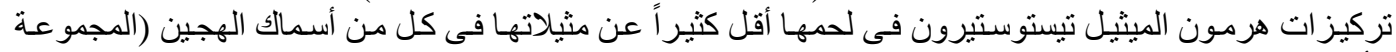

$$
\begin{aligned}
& \text { الأولى) و المجمو عة الضـابطة (الثانية). }
\end{aligned}
$$

